\title{
THE EFFECT OF DIESEL-BIODIESEL BLENDS ON THE PERFORMANCE AND EXHAUST EMISSIONS OF A DIRECT INJECTION OFF-ROAD DIESEL ENGINE
}

\author{
Tomas Mickevičius $^{1}$, Stasys Slavinskas ${ }^{1}$, Slawomir Wierzbicki ${ }^{2}$, Kamil Duda $^{2}$ \\ ${ }^{1}$ Institute of Power and Transport Machinery Engineering, Aleksandras Stulginskis Unvesity, \\ Akademija, Kaunas Region, Lithuania \\ ${ }^{2}$ Dept of Mechatronics and Technical Education Informatics, \\ University of Warmia and Mazury in Olsztyn, Poland
}

Submitted 6 February 2014; resubmitted 14 April 2014; accepted 13 October 2014

\begin{abstract}
This paper presents a comparative analysis of the diesel engine performance and emission characteristics, when operating on diesel fuel and various diesel-biodiesel (B10, B20, B40, B60) blends, at various loads and engine speeds. The experimental tests were performed on a four-stroke, four-cylinder, direct injection, naturally aspirated, $60 \mathrm{~kW}$ diesel engine D-243. The in-cylinder pressure data was analysed to determine the ignition delay, the Heat Release Rate (HRR), maximum in-cylinder pressure and maximum pressure gradients. The influence of diesel-biodiesel blends on the Brake Specific Fuel Consumption $(b s f c)$ and exhaust emissions was also investigated. The bench test results showed that when the engine running on blends B60 at full engine load and rated speed, the autoignition delay was $13.5 \%$ longer, in comparison with mineral diesel. Maximum cylinder pressure decreased about $1-2 \%$ when the amount of Rapeseed Methyl Ester (RME) expanded in the diesel fuel when operating at full load and $1400 \mathrm{~min}^{-1}$ speed. At rated mode, the minimum $b s f c$ increased, when operating on biofuel blends compared to mineral diesel. The maximum brake thermal efficiency sustained at the levels from $0.3 \%$ to $6.5 \%$ lower in comparison with mineral diesel operating at full (100\%) load. When the engine was running at maximum torque mode using diesel - RME fuel blends $\mathrm{B} 10, \mathrm{~B} 20, \mathrm{~B} 40$ and B60 the total emissions of nitrogen oxides decreased. At full and moderate load, the emission of carbon monoxide significantly raised as the amount of RME in fuel increased.
\end{abstract}

Keywords: diesel engine; rapeseed methyl ester; autoignition delay; performance; emissions; opacity of the exhaust.

\section{Introduction}

Internal combustion engine is one of the main users of fossil fuels. Currently, diesel fuel is among the most popular vehicle fuel types. The demand of diesel fuel has been growing constantly during the last two decades. The increase in diesel fuel demand can be explained by the fact that diesel engines are more efficient, use relatively less fuel per engine effective power unit and have a less harmful impact on the environment compared to petrol engines. However, limited reserves of fossil fuels, increasing market prices of mineral fuels and ambient air pollution create problems and impose researchers to investigate a new alternative and renewable energy resource suitable for diesel engine powering. Moreover, the implication of the European Union (EU) Directive 2009/28/EC to use renewable energy in the transport sector in the year 2020 minimum 10\% renewable energy. Currently, biodiesel is a widely used biofuel for diesel engines in many countries. Biodiesel generally is derived from vegetable oils and alcohol in presence of catalyst, defined as mono-alkyl esters of a long chain fatty acids (Knothe 2005). It is considered as renewable, biodegradable, environmental friendly and less toxic fuel in comparison to mineral diesel. The properties of these esters are similar to mineral fuel. Rapeseed oil is the main raw materials for the biodiesel production in the EU (Caresana 2011). The quality of biodiesel in the EU member states is regulated by the EN 14214:2008+A1:2009 standard, which defines the main indicator to be ester content, which depends on biofuel production technology. Fatty acid composition is the indicator, which shows the nature of biodiesel. The purity of this alternative fuel is defined by the free glycerol content, which depends on the manufacturing method as well as product treatment and purification methods (Xue et al. 2011).

The advantage of using biodiesel to diesel engines is the higher content of oxygen in its fatty acid compo-

Corresponding author: Tomas Mickevičius

E-mail: t.mickevicius@yahoo.com 
sition compared with diesel fuels (Torres-Jimenez et al. 2011). Being an oxygenated fuel, it is environmentally cleaner than petrol diesel with respect to hydrocarbon and particulate matter emissions (Som et al. 2010).

Fuel economy is closely connected with exhaust emission, which optimization depends on fuel feed system, engine structure, load, rotational speed of crankshaft, many of the regulated parameters, physical and chemical properties of biofuel and other factors. The calorific value Rapeseed Methyl Ester (RME) is $12.5 \%$ lower than diesel fuel. The cetane number of RME is similar to diesel fuel. Its evaporation rate is lower and the flash point 2.2 times higher, 8 times higher water content and 25 times higher total contamination, it may affect the auto-ignition delay, increase the amount of fuel premixed for rapid combustion and boost the cylinder gas temperature, creating preconditions for $\mathrm{NO}_{\mathrm{x}}$ formation. However, the auto-ignition delay of diesel fuel, especially synthetic biofuel, is not always directly dependent on the cetane number (Labeckas, Slavinskas 2013). The auto-ignition delay depends on the physical properties prevailing in the engine, i.e. the pressure and temperature in the engine combustion chamber. Significant influence on the ignition delay is also held by such factors as combustion chamber shape, compression ratio, chemical structure of fuel and injection characteristics which influence on provision of the combustible blend and temperature variations prior to Top Dead Center (TDC) of the compression stroke. Rakopoulos et al. (2010) carried out the experimental studies on the neat cottonseed oil or its neat (methyl ester) bio-diesel using in diesel engines. The results show that with use of these biofuels against the neat diesel fuel case, the ignition delay was obtained clearly later, depending on the load.

According to Chakravarthy et al. (2007) physical properties of diesel and biodiesel are as a function of temperature, observing that the density, surface tension, and kinematic viscosity of biodiesel are higher than diesel, whereas the vapour pressure and heat capacity are lower. These differences have a significant influence on their spray and combustion characteristics. Som et al. (2010) refer that differences in the spray characteristics of biodiesel and diesel fuels are more pronounced for evaporating sprays compared to those for non-evaporating sprays. This is due to the higher boiling temperature and higher heat of vaporization of biodiesel, implying that vaporization properties rather than fuel physical properties, such as density, viscosity, and surface tension, have a significant influence on spray behaviour.

Van Gerpen et al. (2004) point out that differences of physical chemical and thermodynamically properties of biodiesel and mineral diesel fuel have influence on indicator process of diesel engines and as a result change operational and ecological parameters.

Many scientific studies show that when the engine is running on biodiesel fuel, which has lower calorific value, the brake thermal efficiency is lower and the Brake Specific Fuel Consumption $(b s f c)$ is higher comparing with diesel fuel (McCarthy et al. 2011). Labeckas and Slavinskas (2006) investigated four-stroke, four-cylinders, direct injection, unmodified, naturally aspirated diesel engine when operating on neat RME and its $5 \%, 10 \%, 20 \%$ and $35 \%$ blends with diesel fuel. The $b s f c$ at maximum torque and rated power for RME was higher by $18.7 \%$ and $23.2 \%$ relative to diesel fuel. The maximum brake thermal efficiency varied from 0.356 to 0.398 for RME and from 0.373 to 0.383 for diesel fuel.

Makarevičiene et al. (2013) performed investigation with four-stroke four-cylinder $1 \mathrm{Z}$ type diesel engine of Audi-80, which used 10-30\% RBE and 10-30\% RME compounds. Results indicate that the biologically derived additives improved energy characteristics of the engine, but increased fuel consumption compared to pure diesel.

The emission characteristics of diesel engines operating on neat RME and its blends with diesel fuel have been reported in various research papers. The majority of authors agree that the usage of biodiesel can reduce unburned hydrocarbons (HC), carbon monoxide (CO) and particulate matter (PM) emission, but detected higher levels of nitrogen oxides $\left(\mathrm{NO}_{\mathrm{x}}\right)$ emission (Lapuerta et al. 2008; Nwafor 2004; Nabi et al. 2006).

The experimental study and numerical analysis of injection process show that, while the engine is performed within acceptable limits, harmful emissions can be reduced by adjusting appropriately pump injection timing in dependence on the biodiesel content. In order to reduce harmful engine emissions using biodiesel and mineral diesel fuel blends were investigated by Kegl (2006). Experiments of a common-rail turbocharged direct injection diesel engine at moderate speed and different load torque investigated of the impact of engine injection strategy on $\mathrm{NO}_{\mathrm{x}}$ and $\mathrm{PM}$ emissions with biodiesel fuel (Ye, Boehman 2010). Study confirmed that the dominant factor, which determines $\mathrm{NO}_{\mathrm{x}}$ emissions, is the ignition event controlled by the oxygen equivalence ratio at the autoignition zone.

RME and its blends with mineral fuel impact on the power output of unmodified engine, $b s f c$ and exhaust emission was studied comprehensively but scientific discussions still arise on which RME concentration in diesel fuel could be deemed optimal. The main differences in technical properties of fuel, may affect the autoignition duration, increase the gas amount prepared for the rapid combustion and raise the gas temperature in the cylinder making conditions for the formation of nitrogen oxides more favourable.

The aim of the research was to investigate the influence of the amount of RME in diesel fuel on engine performance and exhaust emission characteristics.

\section{Materials and Methods}

The bench tests were performed on a four-stroke, fourcylinder, direct injection, naturally aspirated diesel engine $\mathrm{D}-243$. The torque of the engine was measured with an electrical AC dynamometer Fig. 1.

The load characteristics of the engine were taken at $1400 \mathrm{~min}^{-1}$ (maximum torque), and $2200 \mathrm{~min}^{-1}$ (rated speed) when operating alternately on diesel fuel, dieselRME blends 10\% RME and 90\% diesel fuel (B10), 20\% 


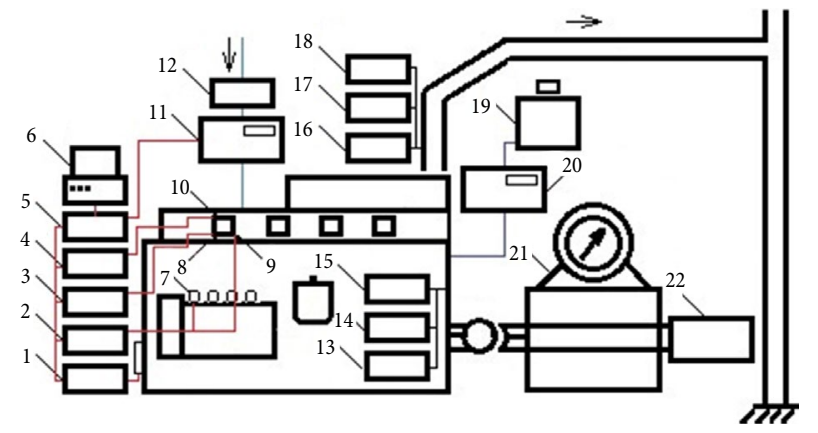

Fig. 1. Engine test bed scheme: 1 - crank angle encoder; 2 - amplifier Kistler 4665; 3 - amplifier Kistler 5247; 4 - amplifier Microifem; 5 - indicating system AVL IndiModul 622; 6 - personal computer; 7, 9 - pressure sensors; 8 - needle valve lifting sensor; 10 - cylinder gas pressure sensor; 11 - air mass flow meter; 12 - air filter; 13, 14 - engine coolant and oil temperature sensors; 15 - engine oil pressure sensor; 16 - thermocouple; 17 exhaust gas analyser; 18 - exhaust smoke meter; 19 - fuel tank; 20 - AVL fuel balance; 21 - dynamometer; 22 - control unit

RME and 80\% diesel fuel (B20), 40\% RME and 60\% diesel fuel (B40), 60\% RME and 40\% diesel fuel (B60).

The fuel mass consumption was measured with the AVL fuel balance with an accuracy of $\pm 0.12 \%$ and the air mass consumption was measured by using the AVL air metering equipment with an accuracy of $\pm 0.25 \%$.

The single-cycle and summarised over 100 engine cycles the in-cylinder gas pressure versus the crank angle were recorded by using the AVL indication and data acquisition system. A piezoelectric uncooled transducer GU24D mounted into the first cylinder and connected to the MICROIFEM piezoelectric amplifier-signal conditioning along with the AVL crank angle encoder 365C $\left( \pm 0.1^{\circ}\right)$ has been used to record gas pressure for every load-speed setting point with an accuracy of \pm 0.1 bar at every 0.1 Crank Angle Degree (CAD). The fuel was injected by an in line fuel injection pump through five holes injection nozzles with the initial fuel delivery at $25^{\circ}$ CADs Before the Top Dead Center (BTDC). The needle valve lifting pressure was set to $19.0 \pm 0.5 \mathrm{MPa}$ for all injectors. To determine the start of injection the history of the nozzle-needle-valve lifting was used which was recorded by using the Hall effects position sensor ASMB 470004-1. The needle-valve lifting signals have been transmitted to the Kistler 5247 amplifier module mounted on the signals conditioning platform Compact 2854A. The AVL IndiModul 622 was introduced as a multi-channel indicating system for the acquisition, processing of crank-angle based cylinder pressure and nozzle-needle-valve lift signals.

The auto ignition delay was determined as the period in degrees (CAD) between the Start Of fuel Injection (SOI) and the Start Of Combustion (SOC). As the start of injection was taken the point, at which the needle-valve lifts about $5 \%$ of its total stroke. As the SOC was taken the point, at which the heat release differential curve crosses the zero line and changes its value from minus to plus one. The Heat Release Rate (HRR) was calculated by using averaged in-cylinder pressuredata of 100 combustion cycles, instantaneous cylinder volume, and their first order derivative with respect to crank angle. The data post-processing was performed with software package AVL CONCERTO ${ }^{\mathrm{m}}$ (http://www. avl.com/concerto).

Fuel used in this research was produced in Poland, Olsztyn city, University Warmia and Mazury, in mobile fuel production laboratory. Fig. 2 presents the interior of the truck with the post reaction products' containers and the reactor. Installation operates periodically and produces approx. 40 litres of esters during one cycle. Once user inserted all necessary ingredients in the reactor, the process continues automatically. Parameters such as mixture temperature, reaction time, inside reactor pressure etc. are controlled automatically. Advantage of this installation is its possibility to collect excess alcohol from post reaction mixture, which must be used during the transesterification process. Containers A, B, C and $\mathrm{D}$ are used to separate esters from glycerine phase. The physical and chemical properties of the fuel, have been investigated in the chemistry laboratory of the university according to EN 14214:2008+A1:2009 standard, as is shown in Table 1.

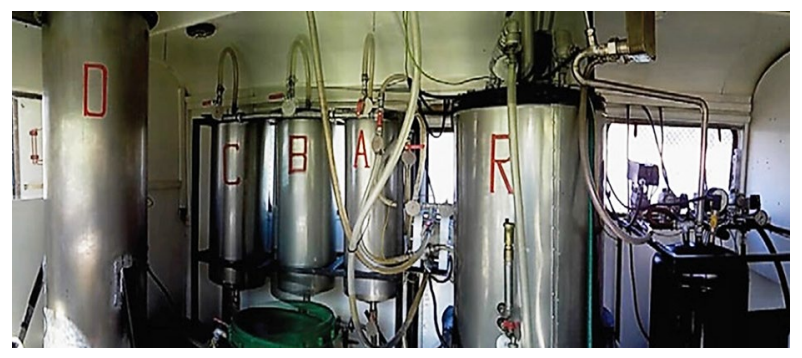

Fig. 2. A panoramic view of a mobile diesel production plant, built on a chassis of a Star 266 vehicle - the transesterification reactor $(\mathrm{R})$ with the post-reaction mixture separators $(\mathrm{A}, \mathrm{B}, \mathrm{C})$

(Piętak et. al. 2012)

The amounts of nitric oxide $\mathrm{NO}$ (ppm), nitrogen dioxide $\mathrm{NO}_{2}$ (ppm), carbon monoxide $\mathrm{CO}$ (ppm), carbon dioxide $\mathrm{CO}_{2}$ (vol\%) and total unburned hydrocarbons $\mathrm{HC}(\mathrm{ppm})$ in the exhausts were measured with the Testo $350 \mathrm{XL}$ gas analyser. Total emissions of nitrogen oxides $\mathrm{NO}_{\mathrm{x}}$ was determined as a sum of both $\mathrm{NO}$ and $\mathrm{NO}_{2}$ gases. The exhaust opacity (\%) was measured with a Bosch RTT 110 opacity-meter. The accuracies of the measured exhaust emission parameters are summarised in Table 2.

Table 1. Properties of RME

\begin{tabular}{lcc}
\hline \multicolumn{1}{c}{ Parameter } & Unit & RME \\
\hline Acid value & $\mathrm{mg} \mathrm{KOH} / \mathrm{g}$ oil & 0.67 \\
\hline Sulphur content & $\mathrm{mg} / \mathrm{kg}$ & 3.22 \\
\hline Density & $\mathrm{kg} / \mathrm{m}^{3}$ & 890 \\
\hline Cinematic viscosity at $40^{\circ} \mathrm{C}$ & $\mathrm{mm}^{2} / \mathrm{s}$ & 5.58 \\
\hline Total contamination & $\mathrm{mg} / \mathrm{kg}$ & 238.61 \\
\hline Oxidation stability & $\mathrm{h}$ & 0.40 \\
\hline Flash point & ${ }^{\circ} \mathrm{C}$ & 122 \\
\hline Calorific value & $\mathrm{MJ} / \mathrm{kg}$ & 38.7 \\
\hline
\end{tabular}


Table 2. The accuracy of measured emission parameters

\begin{tabular}{cc}
\hline Measurements & Accuracy \\
\hline $\mathrm{NO}_{\mathrm{x}}$ & $\pm 5 \mathrm{ppm}$ \\
\hline $\mathrm{CO}$ & $\pm 3 \mathrm{ppm}$ \\
\hline $\mathrm{CO}_{2}$ & $\pm 0.3 \mathrm{vol} \%$ \\
\hline $\mathrm{HC}$ & $\pm 2 \mathrm{ppm}$ \\
\hline Exhaust opacity & $\pm 0.1 \%$ \\
\hline
\end{tabular}

\section{Results and Discussions}

The most important parameters of the diesel combustion process are auto-ignition delay, peak in-cylinder gas pressure, in-cylinder pressure gradients and HRR. Delay period in the diesel engine exerts a very great influence on both engine performance and exhaust emission. During this period some fuel has already been injected into the combustion chamber, but ignition has not yet commenced. Functionally, the ignition delay can be divided in to two components, such as the physical and chemical. The physical processes are the atomisation of the liquid fuel jet, the vaporisation of the fuel droplets, the mixing of the fuel vapour with the air. The chemical processes are pre-combustion reactions of the fuel, air, residual gas mixture, which lead to autoignition. These processes are affected by engine design and performance mode, fuel characteristics (Heywood 1988).

Fig. 3 presents the change of the autoignition delay period on diesel fuel and its blends with RME (B10B60) at different loads and engine speeds of $1400 \mathrm{~min}^{-1}$ and $2200 \mathrm{~min}^{-1}$.

The investigation results show that the autoignition delay increased by $0.9 \%$ (B10), 3.8\% (B20), 6.5\% (B40) and $10.5 \%$ (B60) in comparison with mineral diesel, when engine was operating at low $(b m e p=0.21 \mathrm{MPa})$ load and $1400 \mathrm{~min}^{-1}$ speed. The difference in the autoignition delays between tested blends slightly increased with the increasing engine load. When engine was running at full throttle on blends B10, B20, B40 and B60, the autoignition delay increased by $4.2 \%, 7.5 \%, 8.6 \%$ and $15.9 \%$, respectively, compared with mineral diesel. This means that the combustion process starts later for the higher amount of RME in diesel fuel.

The changes of auto-ignition delay remained the same when the engine was running at the rated $2200 \mathrm{~min}^{-1}$ speed. At low load autoignition delay period has increased by 3\% (B10), 4\% (B20), 12\% (B40) and $14 \%(\mathrm{~B} 60)$. When the engine load increased, the autoignition delay decreased. In case of full engine load, the autoignition delay period increased by $0.6 \%$ (B10), $1.2 \%$ (B20), 4.6\% (B40) and 13.5\% (B60) in comparison with diesel fuel.

Figs 4 and 5 present the maximum in-cylinder pressure and the maximum in-cylinder pressure gradients $(d p / d \varphi)_{\max }$ developed by the combustion of various diesel-biodiesel blends as a function of bmep at engine speeds of $1400 \mathrm{~min}^{-1}$ and $2200 \mathrm{~min}^{-1}$.

It can be concluded that the maximum cylinder pressure increased by $1-4 \%$ in comparison with min-
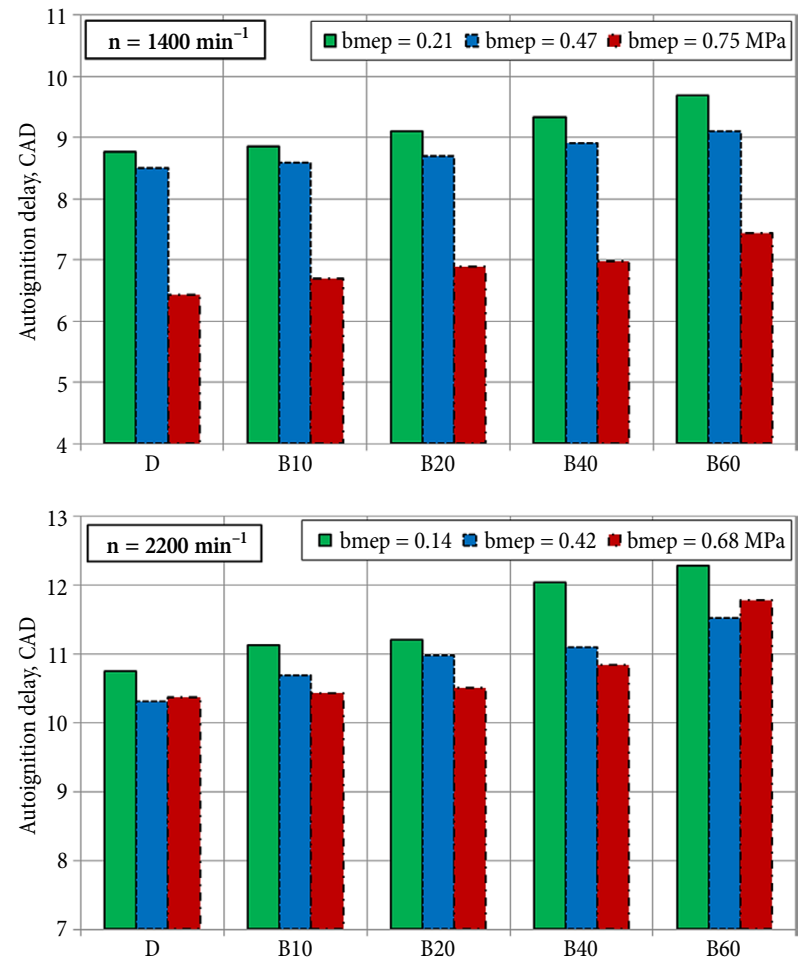

Fig. 3. Dependence of auto-ignition delay on engine load (Brake Mean Effective Pressure - bmep) and RME amount in the fuel
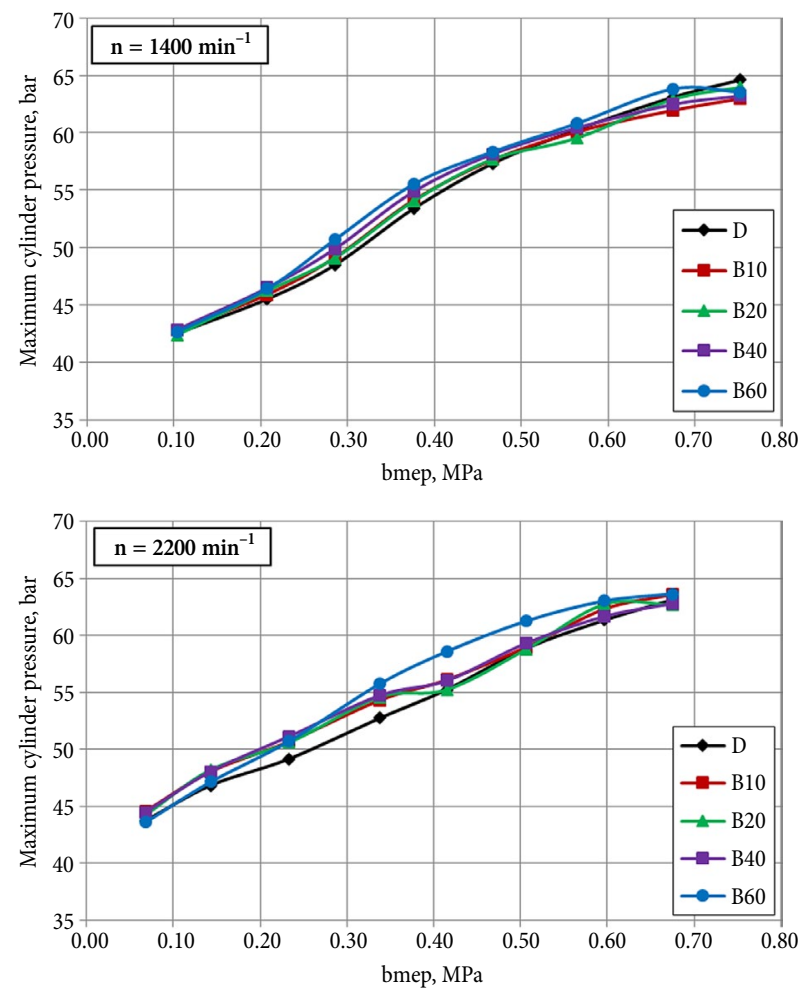

Fig. 4. Dependence of the in-cylinder maximum pressure $\left(p_{\max }\right)$ on engine load $(b m e p)$

eral diesel due to the use of blends B10-B60 at easy to moderate loading conditions and $1400 \mathrm{~min}^{-1}$ speed. The maximum gas pressure was obtained higher because of faster $2.0-7.1 \%$ pressure rise rate $(d p / d \varphi)_{\max }$ (Fig. 5), 
due to the higher autoignition delay period. Considering longer auto-ignition delay larger amount of combustible mixture was prepared. As the engine load was increased, the differences decreased. Despite longer autoignition delay, maximum cylinder pressure gradient using fuel blends B10-B60 was $5.0-0.4 \%$ lower compared to diesel fuel, when engine was operating at full (100\%) load. As the result, peak of in-cylinder pressures was 1-2\% lower when the biofuel blends B10-B60 were used. This contributed to lower biodiesel volatility, which made the evaporation process slower in comparison with diesel fuel.

When the engine speed was rated to $2200 \mathrm{~min}^{-1}$, the peak of in-cylinder pressure reached about $2.3-2.6 \%$ higher for fuel blends B10-B40 compared to diesel fuel when running under low loads $($ bmep $=0.21 \mathrm{MPa})$. Moreover, maximum cylinder pressure gradient raised from $24.1 \%$ to $28.8 \%$ (Fig. 5). When the engine was running on B60 biodiesel blend, the peak of in-cylinder pressure increased hardly $0.56 \%$ despite the maximum cylinder pressure gradient was $20.5 \%$ higher. For the subsequent ignition maximum pressure was reached $1.3^{\circ} \mathrm{CAD}$ later, compared with diesel fuel. This has led to lower the peak of in-cylinder pressure. When the load has been increased the differences were diminishing.

When the engine was operated at moderate load (bmep $=0.42 \mathrm{MPa})$ on fuel blends B10-B60 the maximum cylinder pressure gradient remained from $2.2 \%$ to $18.8 \%$ higher. When the engine was running at maximum load, on diesel fuel and RME blend B60, the peak of in-cylinder pressure was only $1.6 \%$ higher, despite the $14.4 \%$ larger maximum cylinder pressure gradient. This
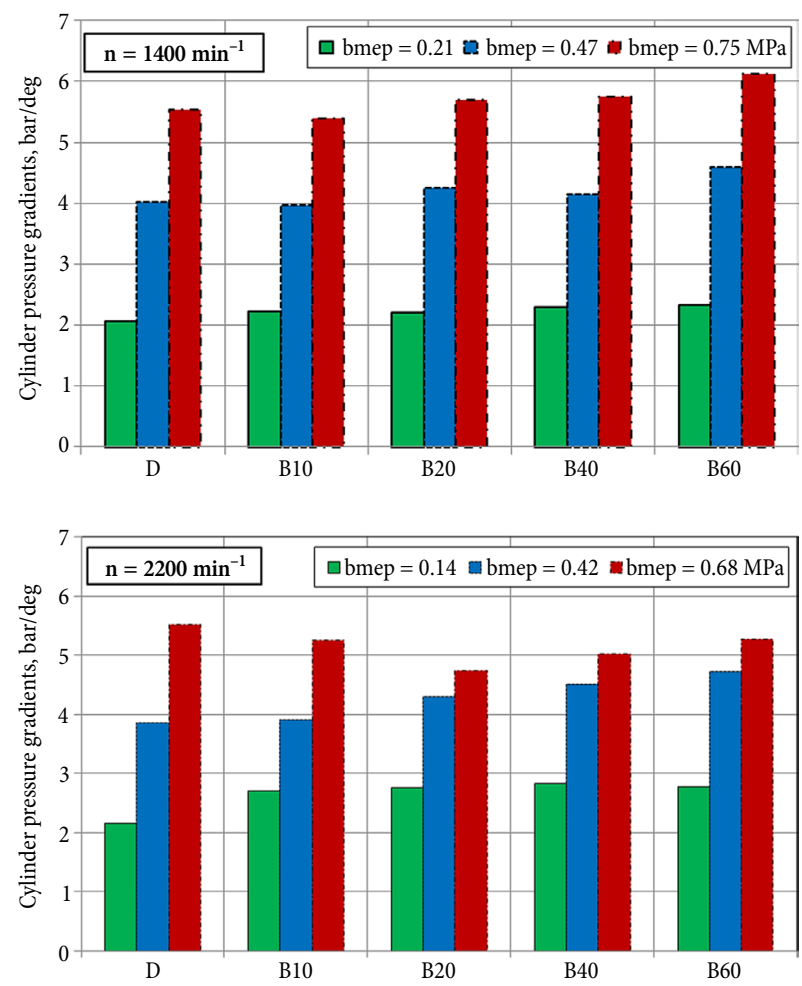

Fig. 5. Dependence maximum cylinder pressure gradient $\left((d p / d \varphi)_{\max }\right)$ on engine load $(b m e p)$ may be due to the combustion process, which moved towards the direction of the expansion stroke. Using biofuel blends B10-B40, the peak of in-cylinder pressure was similar as diesel fuel and the maximum cylinder pressure gradient was $6.6-8.0 \%$ lower.

Fig. 6 presents HRR characteristics when the engine was operating on diesel fuel and RME blends. It should be noted that the increase of the autoignition delay time has influenced the heat release speed in the premixed combustion phase. Maximum HRR for biofuel blends B20, B40, B60 was correspondingly 5.5\%, 4.6\%, $8.2 \%$ higher compared to mineral diesel operating on $1400 \mathrm{~min}^{-1}$ speed and full load ( $b m e p=0.75 \mathrm{MPa}$ ). Furthermore, mentioned peaks were exhibited by $1^{\circ} \mathrm{CAD}$ later than in mineral diesel. Maximum HRR was 3.3\% lower, when the engine was running on fuel blend B10. The speed of HRR was actually the same and maximum values were achieved of the same crankshafts' position as in case of using the mineral diesel fuel. The HRR was $13.3 \%$ higher and its position was reached by $1^{\circ}$ CAD's later when the engine was running at $2200 \mathrm{~min}^{-1}$ speed on biofuel blend $\mathrm{B} 60$, in comparison with conventional diesel.

The changes in combustion process had influence on the engine fuel consumption. Fig. 7 shows, the $b s f c$ for various blends $\mathrm{B} 10-\mathrm{B} 60$ as a function of bmep developed at $1400 \mathrm{~min}^{-1}$ and $2200 \mathrm{~min}^{-1}$ speeds. Under the same engine operating conditions, the $b s f c$ of diesel fuel and RME blends were higher than diesel fuel. $B s f c$ of diesel-biodiesel blends was obtained higher because of lower net heating value of fuel blends. When the engine
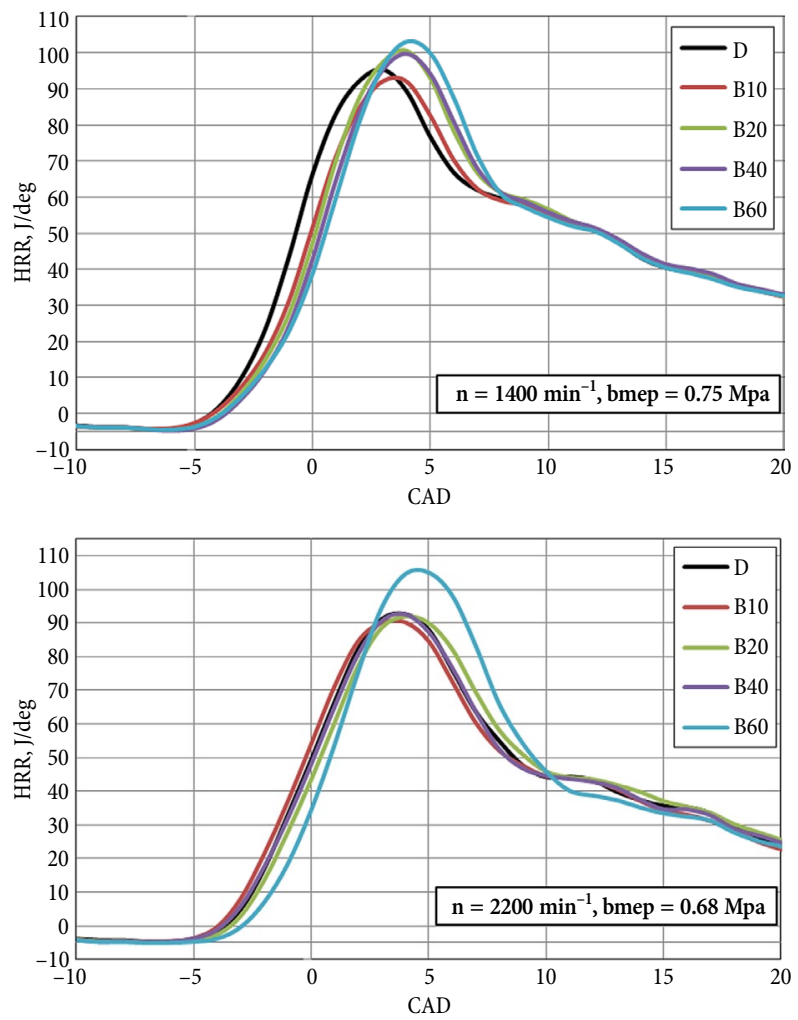

Fig. 6. HRR as function of CAD for the investigated fuels at full engines load and two speeds 
was running on the biofuel blends $\mathrm{B} 10, \mathrm{~B} 20, \mathrm{~B} 40$ and $\mathrm{B} 60$, and the maximum torque mode, the $b s f c$ increases by $0.4 \%, 5.0 \%, 8.0 \%$ and $10.5 \%$, compared to mineral diesel fuel. At the speed of $1400 \mathrm{~min}^{-1}$, the minimum $b s f c$ was obtained by $1.3 \%, 2.7 \%, 6.7 \%$ and $10.7 \%$ higher, respectively. In that case, the engine was operating at maximum torque mode on fuel blend B10, the brake thermal efficiency changed negligibly, in comparison with diesel fuel. Using fuel blends B20-B60, the brake thermal efficiency decreased by $3.1 \%$. When the engine was running at maximum torque speed on diesel fuel, the brake thermal efficiency value was 0.377 . When the engine was operating on biofuel blend B10, B20, B40 and $\mathrm{B} 60$, the brake thermal efficiency decreased by $0.8 \%$, $1.1 \%, 2.1 \%$ and $2.65 \%$ respectively.

Using blends B10, B20 and B40, the bsfc increased by $0.4 \%, 4.6 \%$ and $7.1 \%$, respectively at the rated speed of $2200 \mathrm{~min}^{-1}$ Moreover, the brake thermal efficiency decreased at the same operating conditions by $0.3 \%$, $2.8 \%$ and $2.6 \%$ respectively, comparing with neat diesel fuel. If the amount of RME in the blend was $60 \%$, the $b s f c$ increased by $14.9 \%$, and the brake thermal efficiency decreased by $6.5 \%$, comparing with diesel fuel.

Fig. 8 shows the variation of the nitrogen oxides emissions $\left(\mathrm{NO}_{\mathrm{x}}\right)$ for all used fuels in the study. When the engine was running at the maximum torque mode $1400 \mathrm{~min}^{-1}$ and low load, using of biofuel blends B10, $\mathrm{B} 20, \mathrm{~B} 40$ and $\mathrm{B} 60$ the total emission of nitrogen oxides increased by $10.2 \%, 13.1 \%, 11.5 \%$ and $13.3 \%$, respectively, compared with neat diesel fuel. After the engine load increased to $(b m e p=0.47 \mathrm{MPa})$ the total $\mathrm{NO}_{\mathrm{x}}$ emissions
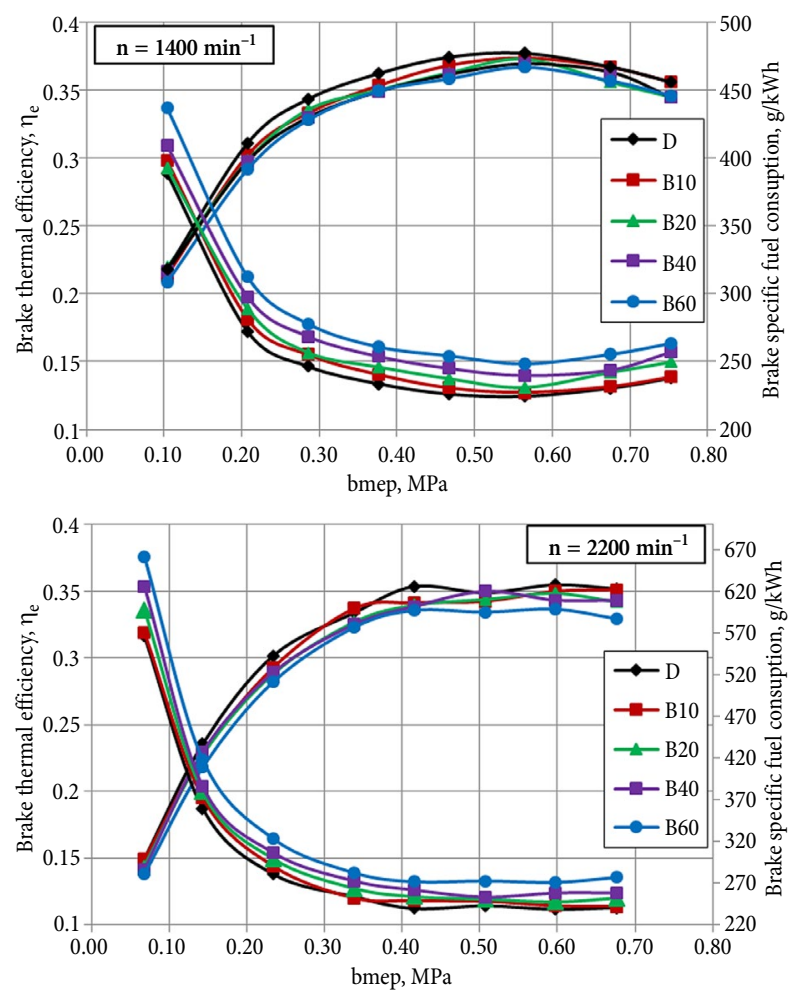

Fig. 7. Dependence of the $b s f c$ and brake thermal efficiency on engine load (bmep) were $3.4 \%$ higher, while the engine is operating only on B10 fuel blend, compared to the mineral diesel fuel. In case of using blends B20, B40 and B60, the emissions of nitrogen oxide were $3.6 \%, 3.3 \%$ and $6.9 \%$ lower. When the engine was running at higher load on biofuel blends $\mathrm{B} 10, \mathrm{~B} 20, \mathrm{~B} 40$ and $\mathrm{B} 60$ the maximum emissions of nitrogen oxides $\mathrm{NO}_{\mathrm{x}}$ decreased by $5.2 \%, 9.4 \%, 16.3 \%$ and $16.8 \%$, respectively. These changes correlated well with the heat release and in cylinder pressure variations.

When the engine was running on biofuel blends B10-B60 at low load and $2200 \mathrm{~min}^{-1}$ speed, the emissions of nitrogen oxides increased by $23 \%, 20 \%, 29 \%$ and $39 \%$, respectively, compared to the mineral diesel fuel. At moderate load $(b m e p=0.42 \mathrm{MPa})$, the $\mathrm{NO}_{\mathrm{x}}$ emission was 3-9\% lower, when the engine was operating on diesel fuel and RME blends. The $\mathrm{NO}_{\mathrm{x}}$ emissions were obtained by $8.6 \%$ higher, when the engine operated on maximum load and biofuel B10 blend. According to the amount of RME in fuel by $20 \%$ and $40 \%$, the $\mathrm{NO}_{\mathrm{x}}$ emissions increased by $2.4 \%$ and $5.6 \%$, respectively. Moreover, the $\mathrm{NO}_{\mathrm{x}}$ emission increased by $1.7 \%$, when the engine is operating on B60 blend, compared to diesel fuel.

Fig. 9 shows, the tendencies emission of carbon monoxide remain similar, when the engine is running at $1400 \mathrm{~min}^{-1}$ speed at low and moderate loads and using diesel and RME blends. Moreover, $\mathrm{CO}$ emissions increased as the amount of RME in the fuel and engine load increased. At full load (bmep $=0.75 \mathrm{MPa})$ and using blend $\mathrm{B} 10$, the $\mathrm{CO}$ emission increased by $24.6 \%$. According to the amount of RME in the fuel by $20 \%, 40 \%$
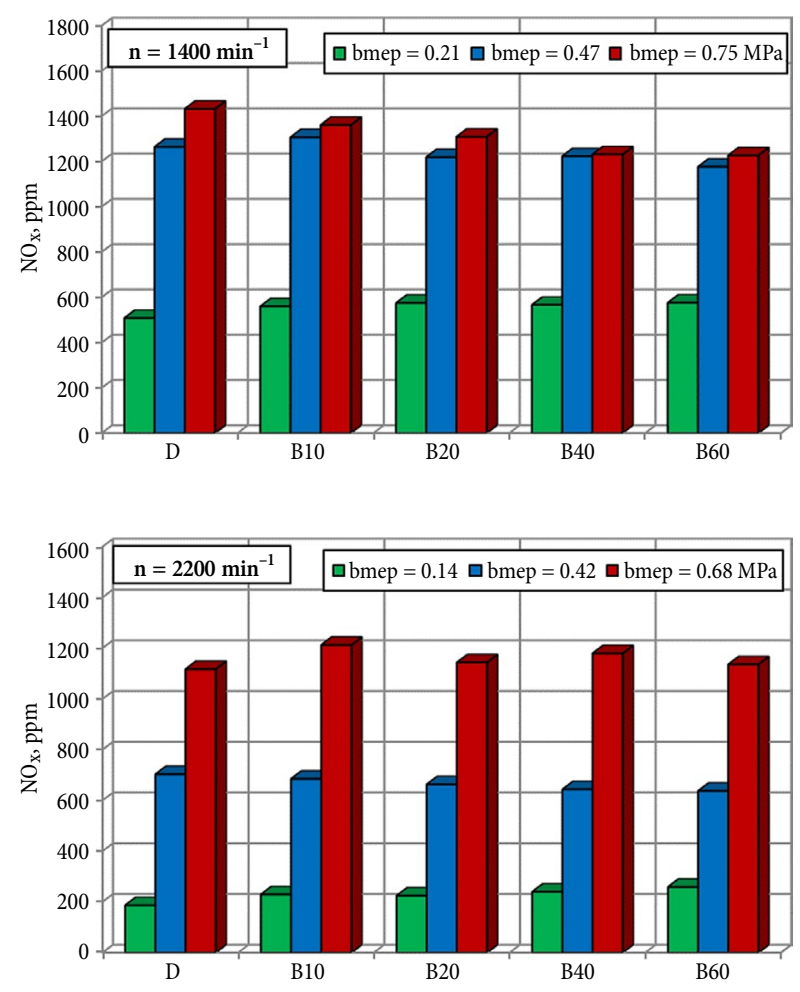

Fig. 8. Influence of the amount of RME in fuel on $\mathrm{NO}_{\mathrm{x}}$ emissions 
and $60 \%$, the $\mathrm{CO}$ emissions increased 2, 3 and 4 times respectively.

When the engine speed increased to the rated $2200 \mathrm{~min}^{-1}$ value, the tendencies of $\mathrm{CO}$ emission change remain similar. At full load, when engine was running on biofuel blend B60, $\mathrm{CO}$ emission was about six times higher, comparing, with diesel fuel. The $\mathrm{CO}$ emission increased about 2.5 times in case of using B20 and B40 fuel blends and using biofuel B10 blend about $51 \%$.

The analysis of data presented in Fig. 10 shows that, when the engine was running on diesel fuel with $10 \%$ mixed RME at low and moderate loads and $1400 \mathrm{~min}^{-1}$ speed, the emission of unburned hydrocarbons (HC) increased by $30-70 \%$. At high load, this difference is about $55 \%$. When the RME amount increases in the fuel, HC emission decreases, except for the maximum torque mode. In case of using biofuel blend B40, $\mathrm{HC}$ emissions were lower or equal comparing with diesel fuel. The HC emission was lower average by $25 \%$, when using biofuel blend B60. When the engine load increased to maximum $($ bmep $=0.75 \mathrm{MPa}$ ) and using biofuel blends B10, $\mathrm{B} 20$ and $\mathrm{B} 40$ the emission of unburned hydrocarbons increased 1.5 times. The $\mathrm{HC}$ emission was twice higher, when engine was operating on B60 fuel blend.

When operating on full engine load range at rated $2200 \mathrm{~min}^{-1}$ speed, emission of unburned hydrocarbons was highest when using the biofuel B10 blend, except the maximum load. When using higher concentration RME in fuel blends the emission of unburned hydrocarbons was lower compared to the mineral diesel fuel. At the maximum load operation the $\mathrm{HC}$ emission has
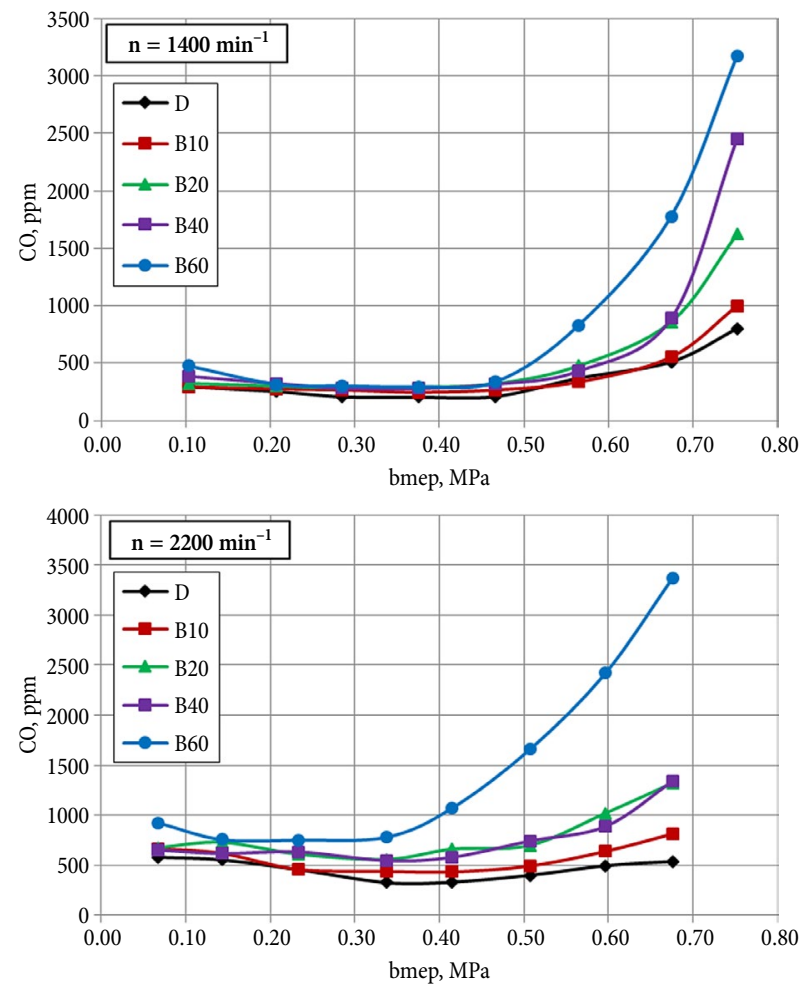

Fig. 9. The $\mathrm{CO}$ emissions as function of engine load (bmep) increased 3 times, compared to the engines performance on mineral diesel fuel. When the engine was operating on biofuel blend B20 and B40, the $\mathrm{HC}$ emission was higher by $28 \%$ and $20 \%$ respectively. In case the engine is operating on biofuel blend $\mathrm{B} 10$, the $\mathrm{HC}$ emission was higher by $36 \%$.

When the engine was running on biofuel blends $\mathrm{B} 10, \mathrm{~B} 20, \mathrm{~B} 40$ and B60 at higher load, the smoke opacity decreased by $33.6 \%, 18.5 \%, 13 \%$ and $20 \%$, respectively, compared to neat diesel fuel (Fig. 11). When the engine operated on $2200 \mathrm{~min}^{-1}$ speed, the tendencies on exhaust opacity remained similar.

\section{Conclusions}

Due to increase in the amount of RME in the fuel blend, the autoignition delay period became longer. In case of full engine load at rated speed, the autoignition delay period increased by $0.6 \%$ (B10), 1.2\% (B20), $4.6 \%$ (B40) and $13.5 \%$ (B60) in comparison with using pure diesel fuel. Maximum cylinder pressure decreased by $1-2 \%$ for biodiesel blends B10, B20, B40, and B60 in comparison with mineral diesel, when engine operated at full load and $1400 \mathrm{~min}^{-1}$ speed.

At rated mode the minimum brake specific fuel consumption increased by $0.4 \%, 4.6 \%, 7.1 \%$, and $14.9 \%$, respectively, when engine was operating on biofuel blends B10, B20, B40 and B60 compared to mineral diesel fuel. Maximum brake thermal efficiency sustained at the levels $0.3 \%$ to $6.5 \%$ lower compared with mineral diesel, when engine operating at full (100\%) load.
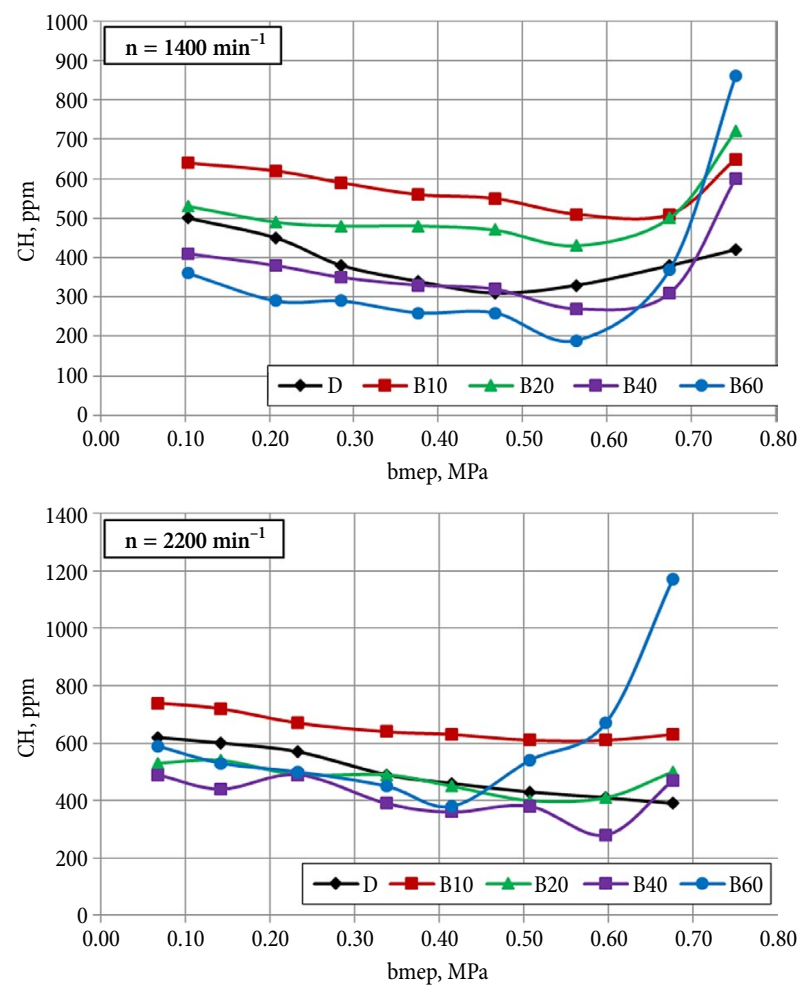

Fig. 10. The unburned hydrocarbons $\mathrm{HC}$ emissions as function of engine load (bmep) 

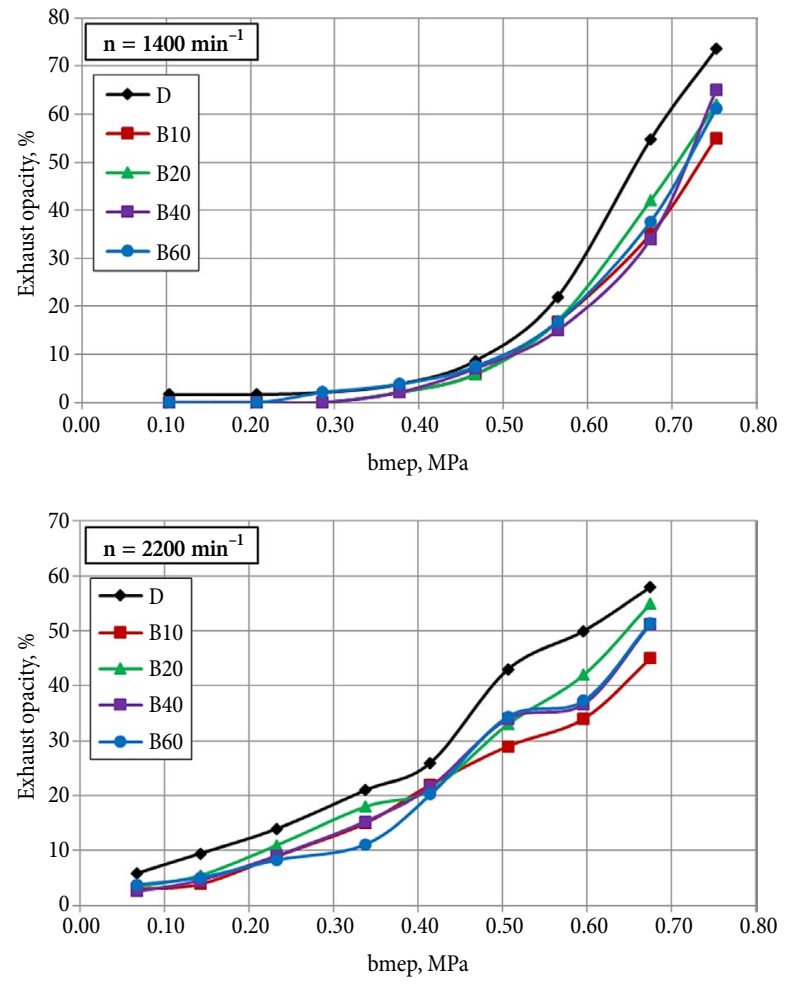

Fig. 11. The smoke opacity of the exhausts as a function of engine load (bmep)

When the engine was running on biofuel blends $\mathrm{B} 10, \mathrm{~B} 20, \mathrm{~B} 40$ and B60 at the maximum torque mode, the total emissions of nitrogen oxides decreased by $9 \%$, $8.6 \%, 14.1 \%$ and $14.4 \%$ respectively, compared to mineral diesel fuel. The highest total emissions of nitrogen oxides $(8.6 \%)$ were measured when the engine was running on fuel blend $\mathrm{B} 10$ at the rated speed. According to the amount of RME in fuel blend $20 \%, 40 \%$ and $60 \%$ the nitrogen oxides emissions increased by $2.4 \%, 5.6 \%$ and $1.7 \%$ respectively.

When the engine was running at high load, carbon monoxide (CO) emission increased significantly according to the increased amount of RME in the fuels. At all engine load range, unburned hydrocarbons emission (HC) was the highest when using the biofuel B10 blend, except the maximum load. Smoke opacity of the exhaust was lower when the engine was operating on diesel fuel and RME blends compared to mineral diesel fuel.

\section{References}

Caresana, F. 2011. Impact of biodiesel bulk modulus on injection pressure and injection timing. The effect of residual pressure, Fuel 90(2): 477-485.

http://dx.doi.org/10.1016/j.fuel.2010.10.005

Chakravarthy, K.; McFarlane, J.; Daw, S.; Ra, Y.; Reitz, R. D.; Griffin, J. 2007. Physical properties of bio-diesel and implications for use of bio-diesel in diesel engines, SAE Technical Paper 2007-01-4030. http://dx.doi.org/10.4271/2007-01-4030
Directive 2009/28/EC of the European Parliament and of the Council of 23 April 2009 on the Promotion of the Use of Energy from Renewable Sources and Amending and Subsequently Repealing Directives 2001/77/EC and 2003/30/EC. Available from Internet: http://eur-lex.europa.eu/LexUriServ/LexUriServ.do?uri=Oj:L:2009:140:0016:0062:en:PDF

EN 14214:2008+A1:2009. Automotive Fuels. Fatty Acid Methyl Esters (FAME) for Diesel Engines. Requirements and Test Methods.

Heywood, J. B. 1988. Internal Combustion Engine Fundamentals. McGraw-Hill Science/Engineering/Math. 930 p.

Kegl, B. 2006. Numerical analysis of injection characteristics using biodiesel fuel, Fuel 85(17-18): 2377-2387. http://dx.doi.org/10.1016/j.fuel.2006.05.009

Knothe, G. 2005. Dependence of biodiesel fuel properties on the structure of fatty acid alkyl esters, Fuel Processing Technology 86(10): 1059-1070.

http://dx.doi.org/10.1016/j.fuproc.2004.11.002

Labeckas, G.; Slavinskas, S. 2013. Performance and emission characteristics of a direct injection diesel engine operating on KDV synthetic diesel fuel, Energy Conversion and Management 66: 173-188.

http://dx.doi.org/10.1016/j.enconman.2012.10.004

Labeckas, G.; Slavinskas, S. 2006. The effect of rapeseed oil methyl ester on direct injection Diesel engine performance and exhaust emissions, Energy Conversion and Management 47(13-14): 1954-1967. http://dx.doi.org/10.1016/j.enconman.2005.09.003

Lapuerta, M.; Armas, O.; Rodríguez-Fernández, J. 2008. Effect of biodiesel fuels on diesel engine emissions, Progress in Energy and Combustion Science 34(2): 198-223. http://dx.doi.org/10.1016/j.pecs.2007.07.001

Makarevičienè, V.; Matijošius, J.; Pukalskas, S.; Vègneris, R.; Kazanceva, I.; Kazancev, K. 2013. The exploitation and environmental characteristics of diesel fuel containing rapeseed butyl esters, Transport 28(2): 158-165.

http://dx.doi.org/10.3846/16484142.2013.801364

McCarthy, P.; Rasul, M. G.; Moazzem, S. 2011. Analysis and comparison of performance and emissions of an internal combustion engine fuelled with petroleum diesel and different bio-diesels, Fuel 90(6): 2147-2157. http://dx.doi.org/10.1016/j.fuel.2011.02.010

Nabi, M. N.; Akhter, M. S.; Zaglul Shahadat, M. M. 2006. Improvement of engine emissions with conventional diesel fuel and diesel-biodiesel blends, Bioresource Technology 97(3): 372-378. http://dx.doi.org/10.1016/j.biortech.2005.03.013

Nwafor, O. M. I. 2004. Emission characteristics of diesel engine operating on rapeseed methyl ester, Renewable Energy 29(1): 119-129.

http://dx.doi.org/10.1016/S0960-1481(03)00133-2

Piętak, A.; Wierzbicki, S.; Duda, K. 2012. Possibility of automation of a mobile biodiesel production plant, Solid State Phenomena 180: 76-88.

http://dx.doi.org/10.4028/www.scientific.net/SSP.180.76

Rakopoulos, C. D.; Rakopoulos, D. C.; Giakoumis, E. G.; Dimaratos, A. M. 2010. Investigation of the combustion of neat cottonseed oil or its neat bio-diesel in a HSDI diesel engine by experimental heat release and statistical analyses, Fuel 89(12): 3814-3826. http://dx.doi.org/10.1016/j.fuel.2010.07.012 
Som, S.; Longman, D. E.; Ramírez, A. I.; Aggarwal, S. K. 2010. A comparison of injector flow and spray characteristics of biodiesel with petrodiesel, Fuel 89(12): 4014-4024.

http://dx.doi.org/10.1016/j.fuel.2010.05.004

Torres-Jimenez, E.; Dorado, M. P.; Kegl, B. 2011. Experimental investigation on injection characteristics of bioethanol-diesel fuel and bioethanol-biodiesel blends, Fuel 90(5): 19681979. http://dx.doi.org/10.1016/j.fuel.2010.11.042

Van Gerpen, J.; Shanks, B.; Pruszko, R.; Clements, D.; Knothe, G. 2004. Biodiesel Analytical Methods. Report No NREL/SR-510-36240. National Renewable Energy Laboratory, Golden, Colorado, US. 100 p. Available from Internet: http://www.nrel.gov/docs/fy04osti/36240.pdf

Xue, J.; Grift, T. E.; Hansen, A. C. 2011. Effect of biodiesel on engine performances and emissions, Renewable and Sustainable Energy Reviews 15(2): 1098-1116. http://dx.doi.org/10.1016/j.rser.2010.11.016

Ye, P.; Boehman, A. L. 2010. Investigation of the impact of engine injection strategy on the biodiesel $\mathrm{NO}_{\mathrm{x}}$ effect with a common-rail turbocharged direct injection diesel engine, Energy \& Fuels 24(8): 4215-4225.

http://dx.doi.org/10.1021/ef1005176 